\title{
Different response of phosphoenolpyruvate carboxylase in two assimilating organs of Hedysarum scoparium on increasing soil water stress
}

\author{
Jia Jia Wang ${ }^{1, a}$, Cong Xia Hu ${ }^{1, b}$ and Chun Mei Gong ${ }^{1, \mathrm{c} *}$ \\ ${ }^{1}$ College of Life Sciences, Northwest A\&F University, Yangling, Shaanxi 712100, China \\ a 846563931@qq.com, ${ }^{\mathrm{b}} 627463533 @ q q . c o m,{ }^{\mathrm{c}} \mathrm{gcm} 228 @ 163 . c o m$ \\ * Chunmei Gong (gcm228@163.com)
}

Keywords: Hedysarum scoparium; Phosphoenolpyruvate carboxylase; Soil water stress.

\begin{abstract}
A typical desert shrub species, Hedysarum scoparium $\left(\mathrm{C}_{3}\right.$ plant $)$ with green rachis, was analyzed on phosphoenolpyruvate carboxylase (PEPC) for considering increasing soil water stress as a probable driving factor to affect assimilation of plant in arid areas. The samples were planted in cultivation plots at depths of $1.4 \mathrm{~m}, 2.4 \mathrm{~m}$ and $3.4 \mathrm{~m}$ sandy soil respectively in this study. Water was periodically supplemented at the bottom of each cultivation plot to simulate soil water stress. The studies of activities of PEPC in two assimilating organs indicated that different photosynthetic organs possess different traits of $\mathrm{CO}_{2}$ fixation. The results showed that PEPC presented both in leaflet and rachis of $H$. scoparium, and enhanced largely with the increasing soil depth. The result suggest that there is a adaptation strategy for desert species with green rachis expanding $\mathrm{C}_{4}$ photosynthesis in $H$. scoparium under severe soil water deficit.
\end{abstract}

\section{Introduction}

The anatomical and photosynthetic physiological changes of photosynthesis can emerge from $\mathrm{C}_{3}$ to $\mathrm{C}_{4}$ as evolutionary adaptations to environment in land plants [1]. Soil drought is one of the most important factors promoting this variation [2]. There exist several photosynthetic key enzymes both in $\mathrm{C}_{3}$ and $\mathrm{C}_{4}$ plants. During the initial fixation of $\mathrm{CO}_{2}$, phosphoenolpyruvate carboxylase (PEPC, EC 4.1.1.31) plays a key role in $\mathrm{C}_{4}$ plants [3]. It increases in $\mathrm{C}_{4}$ plants [4], but it increases, decreases or keeps unchangeable in $\mathrm{C}_{3}$ plants [5].

Desert plants often experience a series of conditions that may cause stresses while water deficit is perhaps the fatal factor impacting adversely on plant growth and development [6]. Haloxylon ammodendron (Chenopodiaceae) and Hedysarum scoparium (Leguminosae) are two dominanted shrubs of the sandy deserts and arid regions across northwest China [7].

H. scoparium is a small-leaf desert species, and some photosynthetic attributes of $\mathrm{H}$. scoparium leaflets is known well, but little is known about other assimilating organs. Previous research showed that $\mathrm{C}_{4}$ photosynthesis can function within a single photosynthetic cell, without Kranz anatomy [2]. Desert $\mathrm{C}_{3}$ species tend to develop their photosynthetic types with the increasing environmental stress, which results in emergence of $\mathrm{C}_{4}$ pathway in assimilating organs.

In this study, $H$. scoparium was look upon as typical desert species to give clues for adaptation environment, especially the $\mathrm{C}_{4}$ photosynthetic enzymatic adaptable characteristics of $\mathrm{C}_{3}$ desert species. A specific hypothesis underlying the present studies was that desert $\mathrm{C}_{3}$ species may develop their photosynthetic types and form some properties of $\mathrm{C}_{4}$ mode in assimilating organs under water stress.

\section{Materials and Methods}

Experimental conditions and design. The study was carried out near the town of Minqin $\left(38^{\circ} 38^{\prime} \mathrm{N}\right.$, $\left.103^{\circ} 05^{\prime} \mathrm{E}\right)$, northwest China. The average annual precipitation is $115 \mathrm{~mm}$, maily distributing from July to September. The aridity is 5.3, annual average evaporation is $2643.9 \mathrm{~mm}$ and annual average temperature is $7.8^{\circ} \mathrm{C}$ with the highest temperature of $38.1^{\circ} \mathrm{C}$ and the lowest temperature of $-28.8^{\circ} \mathrm{C}$. 
The non-frost period reaches up to 165 days each year. The soil type is sandy soil and average depth of groundwater is $18 \mathrm{~m}$.

The two years old seedlings of $\mathrm{H}$. scoparium were grown outdoors in cultivated three chambers filled with sandy soil. Cultivated chambers were $1 \mathrm{~m}$ in length and width, and $1.6 \mathrm{~m}, 2.6 \mathrm{~m}$ or $3.6 \mathrm{~m}$ in depth. 3 depths of ground water (DGW) were established, $1.4 \mathrm{~m}, 2.4 \mathrm{~m}$ and $3.4 \mathrm{~m}$ [9]. The soil water content from every $20 \mathrm{~cm}$ in depth was monitored by measuring fresh and dry weight of soil.

Leaflet and rachis of $H$. scoparium were sampled and frozen in liquid nitrogen immediately after sampling.

Determination of water content. Three replicate soil samples were collected every $20 \mathrm{~cm}$ depth from holes that were randomly drilled in each treatment. Soil water content was determined gravimetrically after drying the samples in an oven at $105^{\circ} \mathrm{C}$ for 24 hours.

The relative water content (RWC) of leaves were estimated by recording the fresh mass (FM) and the saturated mass (SM) of $0.5 \mathrm{~g}$ fresh leaf samples by keeping in water for $24 \mathrm{~h}$, followed by drying in hot air oven till constant dry mass (DM) is achieved according to the method of Barrs et al. [10].

$\mathrm{RWC}(\%)=((\mathrm{FM}-\mathrm{DM}) /(\mathrm{SM}-\mathrm{DM})) \times 100 \%$

Enzyme extraction and assay. For extraction of photosynthetic key enzymes, aliquots of 100mg powdered plant tissue were carried out using a previously described method [9]. The activity of PEPC was monitored spectrophotometrically by the method described by Ting and Osmond [11]. The $1 \mathrm{ml}$ assay medium contained $50 \mathrm{mmol} \mathrm{L}{ }^{-1}$ Tris- $\mathrm{HCl}(\mathrm{pH} 8.0), 5 \mathrm{mmol} \mathrm{L}^{-1} \mathrm{MgCl}_{2}, 2 \mathrm{mmol} \mathrm{L} \mathrm{LTT}^{-1} \mathrm{DT}$ mmol L $\mathrm{NaHCO}_{3}, 0.2 \mathrm{mmol} \mathrm{L}^{-1} \mathrm{NADH}, 0.1 \mathrm{mmol} \mathrm{L}^{-1}$ EDTA, 3 units malate dehydrogenase and 20 $\mu \mathrm{l}$ extract. The reaction was initiated with $2 \mathrm{mmol} \mathrm{L}^{-1}$ PEP.

Statistical analysis. The data harvested and statistical significance of means of three replicates was judged by the least significant difference (LSD) test at 0.05 and 0.01 probability level.

\section{Results and Discussion}

Moisture state of desert plant. Soil moisture gradually increased with the increasing soil depth in three chambers. Accordingly, the RWC either in leaflets or in rachis of $H$. scoparium in different plot was varied, and the water potential / RWC in leaflets were all higher than that in rachis, and reached a peak at 15:00 as shown in Figure 1.

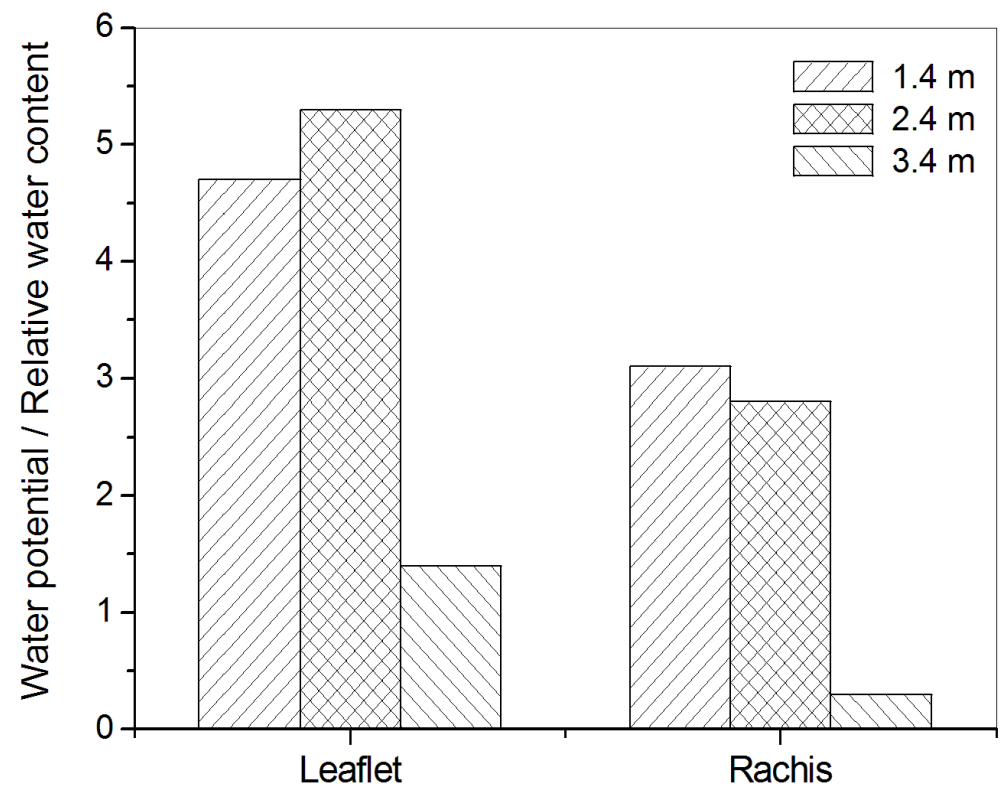

Figure. 1 Changes of water potential/RWC in leaflets and rachis of Hedysarum scoparium at three depths of ground water at 9:00. 
Water potential / RWC can reflect the water availability. Water availability is an important factor affecting photosynthetic activity of plant species [12]. Our results showed that photosynthetic and growth latent capacity of leaflet and rachis was restricted with increase of soil depth, which indicated that rachis might develop its $\mathrm{C}_{4}$ photosynthetic characteristics in severe water condition, also might explain that many species have formed assimilation organs like cylindrical green shoot which reduce transpiration and performed photosynthesis against overexploitation of ground water in Minqin areas. In addition, this result also corresponded to the fact that activities of SOD and POD in rachis were improved with increasing soil drought in H. scoparium during midday [13].

Activities of $\mathbf{C}_{\mathbf{4}}$ photosynthetic key enzymes. The activities of $\mathrm{C}_{4}$ photosynthetic key enzymes in leaflets were all higher than those in rachis of $H$. scoparium at three depths of ground water. Activity of PEPCase in leaflets reached the top at 9:00 (ca. $4.4 \mu \mathrm{mol} \mathrm{PEP} \mathrm{min}^{-1} \mathrm{mg}^{-1}$ protein) in $3.4 \mathrm{~m}$ depths of ground water when it stayed a relatively lower level in rachis (ca. $3.3 \mu \mathrm{mol} \mathrm{min} \mathrm{mg}^{-1}$ protein). As the DGW is deeper and deeper, activity of PEPC in leaflets had a dropping and then had a little increase, and counterpart in rachis increased at the same time (Table 1), which is contrast to the changes of water content of plant. Meanwhile, we found changes of $\mathrm{C}_{4}$ photosynthetic key enzyme consist with protein content changes of enzymes. This suggested the increase in activity was a result of protein synthesis rather than light-activation of pre-existing protein.

Table 1 PEPCase activities in leaflets and rachis of Hedysarum scoparium at 9:00 at three depths of ground water.

\begin{tabular}{|c|c|c|c|}
\hline \multirow{2}{*}{ Organs } & \multicolumn{3}{|c|}{ PEPC activity ( $\mu \mathrm{mol} \mathrm{min}^{-1} \mathrm{mg}^{-1}$ protein) } \\
\hline & $1.4 \mathrm{~m}$ & $2.4 \mathrm{~m}$ & $3.4 \mathrm{~m}$ \\
\hline Leaflet & $4.28 \pm 0.75 \mathrm{a}$ & $2.95 \pm 0.32 b$ & $4.36 \pm 1.21 \mathrm{a}$ \\
\hline Rachis & $2.06 \pm 0.52 \mathrm{~A}$ & $2.07 \pm 0.98 \mathrm{~A}$ & $3.31 \pm 0.94 \mathrm{AB}$ \\
\hline
\end{tabular}

Our results suggested that varying soil water stress plays a significant role in the distribution and ecophysiological features of different photosynthetic types and even develops the photosynthetic pathways. The intrinsic link between photosynthesis and biomass production suggests that photosynthetic response to drought probably play a major role in determining the ability of these species to persist in drought areas [14], also in consideration of global change. Furthermore, this activity was significantly high in each non-leaf organ [15]. As PEPC activity is positively and negatively regulated by metabolites [16], the ubiquity of these $C_{4}$ cycle enzymes in $C_{3}$ plants indicates that these ' $\mathrm{C}_{3}$ isoforms' serve as the starting point for the evolution of the $\mathrm{C}_{4}$ genes [17]. The multiple independent origin of $\mathrm{C}_{4}$ photosynthesis suggested that the species evolution from $\mathrm{C}_{3}$ to $\mathrm{C}_{4}$ must have been relatively easy in genetic terms [18]. Our results suggest that there is the adaptable mechanism and evolutional direction of organs of $\mathrm{C}_{3}$ desert species in deteriorated soil moisture circumstance, and under the conditions of high photon flux and high temperature in desert areas.

In conclusion, $\mathrm{C}_{4}$ key photosynthetic enzymes in $\mathrm{C}_{3}$ species $H$. scoparium presented an increasing thriving trend with the increasing degree of soil water stress. Therefore, we proposed a hypothesis that organs diversity of $\mathrm{C}_{4}$ photosynthesis in $\mathrm{C}_{3}$ desert species is an important indicator for plant growth, survival and evolutional transition in arid regions.

\section{Acknowledgements}

This work is financed by the National Natural Science Foundation of China (No.: 31070538) and the Fundamental Research Funds for the Central Universities (No.: QN2011026). 


\section{References}

[1] C.M. Gong, P.B. Ning, G.X. Wang, Z.S. Liang, A review of adaptable variations and evolution of photosynthetic carbon assimilating pathway in $\mathrm{C}_{3}$ and $\mathrm{C}_{4}$ plants, J Plant ecol. 33 (2009) 206-221.

[2] R.F. Sage, The evolution of $\mathrm{C}_{4}$ photosynthesis, New Phytol. 161 (2004) 341-370.

[3] U. Gowik, P. Westhoff, The path from $\mathrm{C}_{3}$ to $\mathrm{C}_{4}$ photosynthesis, Plant Physiol, 155 (2011) 56-63.

[4] C.H. Foyer, M.H. Valadier, A. Migge, T.W. Becker, Drought-induced effects on nitrate reductase activity and mRNA and on the coordination of nitrogen and carbon metabolism in maize leaves, Plant Physiol. 117 (1998) 283-292.

[5] A.E. Carmo-Silva, A.S. Soares, J. Marques da Silva, A. Bernardes da Silva, A.J. Keys, M.C. Arrabaça, Photosynthetic responses of three $\mathrm{C}_{4}$ grasses of metabolic subtypes to water deficit, Funct Plant Biol. 34 (2007) 204-213.

[6] G. Han, Z. Zhao, Light response characteristics of photosynthesis of four xerophilous shrubs under different soil moistures, Acta Ecol. Sin. 30 (2010) 4019-4026.

[7] P.X. Su, T.T. Xie, Z.J. Zhou, $\mathrm{C}_{4}$ plant species and geographical distribution in relation to climate in the desert vegetation of China, Sciences in Cold and Arid Regions. 3 (2011) 0381-0391.

[8] L.G. Zhang, F.J. Zeng, B. Liu, Z. Liu, G.X. An, H.F. Li, N. Yuan, Study of the photosynthesis characteristics and physical signs of four plants at the desert-oasis ecotone, Acta Ecol. Sin. 21 (2012) 103-111.

[9] C.M. Gong, X.W. Gao, D.L. Cheng, G.X. Wang, $\mathrm{C}_{4}$ photosynthetic characteristics and antioxidative protection of $\mathrm{C}_{3}$ desert shrub Hedysarum scoparium in Northwest China, Pak $\mathrm{J}$ Bot. 38 (2006) 647-661.

[10] H.D. Barrs, P.E. Weatherley, A re-examination of the relative turgidity technique for the estimating of water deficits in leaves, AJCS. 15 (1962) 413-428.

[11] I.P. Ting, C.B. Osmond, Photosynthetic phosphoenolpyruvate carboxylase characteristics of alloenzymes from leaves of $\mathrm{C}_{3}$ and $\mathrm{C}_{4}$ plants, Plant Physiol. 51 (1973) 439-447.

[12] L. Llorens, J. Peñuelas, I. Filella, Diurnal and seasonal variations in the photosynthetic performance and water relations of two co-occurring Mediterranean shrubs, Erica multiflora and Globularia alypum, Physiol Plantarum. 118 (2003) 84-95.

[13] C.M. Gong, J. Bai, G.X. Wang, C.L. Cao, The antioxidative protection strategies of different organs in Hedysarum scoparium under water stress at midday, J Nor For Uni. 24 (2009) 15-19.

[14] J. Gulías, J. Flexas, A. Abadía, H. Medrano, Photosynthetic response to water deficit in six Mediterranean sclerophyll species: possible factors explaining the declining distribution of Rhamnus ludovici-salvatoris, an endemic Balearic species, Tree physiol. 22 (2002) 687-697.

[15] X.L. Xu, Y.H. Zhang, Z.M. Wang, Effect of heat stress during grain filling on phosphoenolpyruvate carboxylase and ribulose-1,5-bisphosphate carboxylase/oxygenase activities of various green organs in winter wheat, Photosynthetica. 42 (2004) 317-320.

[16] Y. Kai, H. Matsumura, K. Izui, Phosphoenolpyruvate carboxylase: three dimensional structure and molecular mechanisms, Arch Biochem Biophys. 414 (2003) 170-179.

[17] R.K. Monson, The origins of $\mathrm{C}_{4}$ genes and evolutionary pattern in the $\mathrm{C}_{4}$ metabolic phenotype, In: Sage, R.F., Monson, R.K., eds. C 4 Plant Biology. San Diego: Academic Press. (1999) 377-410.

[18] J.M. Hibberd, J.E. Sheehy, J.A. Langdale, Using $\mathrm{C}_{4}$ photosynthesis to increase the yield of rice-rationale and feasibility, Curr Opin Plant Biol. 11 (2008) 228-231. 